\title{
LA MUJER SE VISTE PARA EL DEPORTE: LOS ORÍGENES DE LA INDUMENTARIA DEPORTIVA FEMENINA EN ESPAÑA
}

\author{
Mercedes Rodríguez Collado \\ Museo Nacional del Romanticismo \\ merodcol@gmail.com \\ Fecha de recepción: Marzo 2020 \\ Fecha de aceptación: Abril 2020
}

Doi: http://doi.org/10.15366/citius2020.13.1.003

\section{Resumen:}

En los últimos años del siglo XIX vamos a asistir al desarrollo del deporte femenino en nuestro país. Las mujeres de la burguesía y nobleza van a descubrir los diferentes sports que, originarios del Reino Unido, ahora se ponen de moda. Esto hace necesario la creación de una indumentaria adecuada para la práctica de estas actividades que reflejan la nueva vida de la mujer activa. Si Francia se convierte en el siglo XIX en el adalid de la moda urbana, será Gran Bretaña el país donde se cree la indumentaria deportiva o sportwear.

La vestimenta femenina para el deporte va a tener su origen en dos prendas surgidas hacia 1850; por un lado, el bloomer, pantalón ideado por las sufragistas americanas y que fue utilizado para practicar el ciclismo, actividad seguida por un gran número de mujeres. Por otro lado, el traje sastre o tailleur, nacido de la mano del modisto Redfern; esta prenda será el modelo que servirá de base a la indumentaria empleada por las damas para ejercitarse en deportes como la hípica, el lawn tennis, el golf o el patinaje. Las revistas femeninas describirán con todo lujo de detalles estos trajes deportivos, acompañados, además, con figurines, que servirán de inspiración a los sastres y modistas encargados de su fabricación.

Palabras clave: Deporte, mujer, indumentaria deportiva, Bloomer, traje sastre.

Title: WOMEN DRESS FOR SPORT: THE ORIGINS OF WOMEN'S SPORTWEAR IN SPAIN

\begin{abstract}
:
In the last years of the nineteenth century we will attend the development of women's sports in our country. The women of the bourgeoisie and nobility will discover the different sports that, originally from the United Kingdom, now become fashionable. This necessitates the creation of appropriate clothing for the practice of these activities that reflect the new life of the active woman. If France becomes the champion of urban fashion in the nineteenth century, Britain will be the country where sportwear is created.

The feminine clothing for the sport will have its origin in two garments that emerged around 1850; on the one hand the bloomer, pants designed by the American suffragists and that was used to practice cycling, an activity followed by a large number of women. On the other hand, the suit tailor or tailleur, born of the hand of the couturier Redfern; This garment will be the model that will serve as the basis for the clothing used by the ladies to exercise in sports such as horse riding, lawn tennis, golf or skating. Women's magazines will describe in detail these sports suits, accompanied, in addition, with figurines, which will serve as inspiration for tailors and dressmakers in charge of their manufacture.
\end{abstract}

Key Words: Sport, women, sportwear, Bloomer, tailor-made

\section{Introducción}

El deporte, tal y como hoy lo conocemos, surgió en el Reino Unido en el siglo XIX. Concebida como una actividad de élite, era practicada por miembros de la burguesía y la nobleza. En aquel momento tenía un carácter lúdico llevándose a cabo generalmente al aire libre. Se consideraba un ejercicio saludable y un juego de competición y de distracción. El concepto de 
sport identificaba las costumbres ociosas de las elegantes sociedades de Inglaterra y Francia, que posteriormente se difundieron por otros países europeos entre los que se encontraba España. En este sentido, se desarrollaron prácticas deportivas como la equitación, el patinaje, la caza o las regatas de vela. También nuevos sports como el lawn-tennis, el croquet o el ciclismo.

En un principio, la mujer tuvo un acceso muy limitado a la actividad deportiva, ya que era considerada como un ser débil, con menor capacidad física que el hombre, y, por lo tanto, con un cuerpo que no estaba capacitado para la práctica de los diferentes deportes. El destino de las damas en este momento era el ámbito doméstico: tener hijos y cuidar de la familia y la casa.

\section{El deporte en España}

Aunque con cierto retraso con respecto a Europa, la incorporación de la práctica del deporte moderno en España se inició durante la segunda mitad del siglo XIX. Varios factores influyeron en ello.

Por un lado, la presencia de diferentes miembros de la sociedad extranjera, ingleses generalmente, que se encontraban en España trabajando en distintas empresas y que practicaban asiduamente sports traídos de su país.

Otro factor que influyó de forma determinante fueron las políticas en relación con la enseñanza de la gimnasia. No fue hasta 1845 con el Plan Pidal, debido a D. Pedro Pidal y Mon, modificado en 1847 por el Plan de D. Nicomedes Pastor Díaz, cuando aparezca la Gimnástica como materia escolar. ${ }^{1}$ Durante el último cuarto del siglo XIX la Educación Física se desarrolló en los programas escolares liberales y progresistas y se suprimió en los elaborados por gobiernos conservadores. El impulso definitivo lo dio Manuel Becerra, con la promulgación de la ley de 31 de octubre de $1881 .^{2}$

Podemos afirmar que uno de los principales impulsores de la Educación Física y su implantación oficial en la escuela, fue la Institución Libre de Enseñanza (I.L.E). Esta institución promovió activamente el deporte en sus programas escolares, pasando a convertirse en rasgo característico de su estilo educativo. La I.L.E. abogó, asimismo, por unos novedosos métodos de Educación Física. ${ }^{3}$ Estimuló el juego e introdujo la práctica de deportes nuevos como el cricket, el tenis, el fútbol o el cross. Un aspecto muy importante de su sistema educativo fue la inclusión de la mujer en estas actividades deportivas.

Desde la segunda mitad del siglo XIX, los escritores comenzaron a ocuparse de fenómenos, entonces nuevos, como el deporte y la gimnasia. Entre todos ellos hemos de destacar a Emilia Pardo Bazán, literata decimonónica que publicó numerosas crónicas en las que abogaba por el desarrollo de la Educación Física femenina. Defendió la existencia de maestros

\footnotetext{
${ }^{1}$ Se está omitiendo, por su escasa presencia temporal, la introducción de la gimnasia que llevó a cabo el valenciano Francisco de Amorós y Ondeano, Marqués de Sotelo, dentro del plan de estudios del Real Instituto Pestalozziano de Madrid, (1806-1808) sito en la calle del Pez. Método de gimnasia original creado por este español que acabó, como su creador, en el exilio en Francia. Como es sabido, su éxito en tierras galas es recogido en la bibliografía internacional especializada como "La Escuela Gimnástica francesa del siglo XIX", siendo uno de los tres métodos de gimnasia reconocidos por la historiografía como el origen y la base en la que se desarrolló la Educación Física en toda Europa y América.

${ }^{2}$ Martínez Navarro, A. (1983). Anotaciones a la historia de la Educación Física española en el siglo XIX, Historia de la educación: Revista interuniversitaria,2, 155-156. http://campus.usal.es/ revistas_trabajo/index.php/0212 0267/article/viewFile/6476/6478. [Consultado 3-11-2010]

${ }^{3}$ Martínez-Gorroño, M.E. y Hernández-Álvarez, J.L. (2014). La Institución Libre de Enseñanza y Pierre de Coubertin: la educación física para una formación en libertad / The free institute of education and Pierre de Coubertin: physical education to educate within liberty. Revista Internacional de Medicina y Ciencias de la Actividad Física y el Deporte, 14(54), 243-263. Http://cdeporte.rediris.es/revista/revista54/artinstitucion458.htm
} 
especialistas en una gimnasia ${ }^{4}$ concebida como juego y como actividad educativa, tal como ocurría en otros países de Europa. Pardo Bazán dedicó también algunos artículos a las nuevas prendas de moda para la mujer: la falda pantalón o el pantalón.

Las nuevas revistas que surgieron en España en el último tercio del siglo XIX fueron determinantes en la difusión de estos deportes: El 1 de diciembre de 1876 se publicaba en Madrid el primer ejemplar de «El Campo: agricultura, jardinería y sport» (1876-1881) una revista quincenal dirigida por el Conde de las Cinco Torres. Estaba dedicada a difundir ciertos aspectos culturales, botánicos, sociales y costumbristas de la alta sociedad española, y a describir los deportes que se practicaban en España en este momento. El semanario «El sport español», aparecido en Barcelona en 1885, fue el primer periódico especialmente dedicado a los deportes. En Madrid, «La Semana Madrileña» (1883), subtitulada Revista de salones, teatro y sport, acogió igualmente la información deportiva.

En 1906 tuvo lugar la boda de Alfonso XIII con Victoria Eugenia de Battenberg; este hecho influyó de forma significativa en el progreso del deporte en nuestro país. Los reyes y sus hijos, sin duda influenciados por la moda del sport inglés que la reina debió inculcar en su familia, fueron asiduos practicantes de las distintas disciplinas deportivas que en estos años estaban en boga: golf, patinaje o lawn tennis. Existen numerosos documentos gráficos que muestran a la familia real dedicándose a la práctica de estas actividades en los diferentes palacios de su propiedad: La Granja en Segovia, La Magdalena en Santander, Aranjuez o El Palacio Real en Madrid. A imagen y semejanza del Rey y su familia, un gran número de nobles y aristócratas españoles descubrieron los deportes, participando activamente en la creación de diferentes clubes donde tenían lugar distintas competiciones deportivas. ${ }^{5}$

\section{Los clubes deportivos}

Estos elitistas círculos de carácter privado aparecieron hacia 1850. Originados en la Inglaterra victoriana, se implantaron en las principales ciudades europeas como símbolo de prestigio social, estableciéndose alrededor de una actividad deportiva.

Los clubes deportivos estaban compuestos por personajes de la aristocracia y la burguesía de la época. Eran las únicas clases sociales que podían permitirse el lujo de acceder a unos exclusivos y caros clubes de polo, golf, patinaje o lawn tennis. Asimismo, tenían el suficiente poder económico para adquirir palos, patines, raquetas y las diferentes prendas de indumentaria adecuadas a la práctica de estos deportes.

La fuerte endogamia social que existía en aquel momento propició estos exclusivos centros deportivos, ya que la pertenencia a estos clubes se consideró, asimismo, un medio de relación idóneo entre los jóvenes de la alta sociedad en vistas a un futuro matrimonio. De esta forma, se fomentó la práctica del deporte tanto de hombres como de mujeres.

En nuestro país surgieron en el siglo XIX una serie de clubes y sociedades deportivas cuyos socios pertenecían fundamentalmente a la aristocracia, al ejército y la clase política española. En 1878 se fundaron la Sociedad Velocipedista Madrileña y el Club Velocipédico de Cádiz. Ha sido señalada la Sociedad Gimnástica Española (SGE), nombrada Real Sociedad Gimnástica Española (RSGE) por el Rey Alfonso XIII en 1916 y fundada en Madrid el año 1887,

\footnotetext{
${ }^{4}$ Aspecto que en forma pionera ya Jovellanos había planteado en el proyecto educativo "Bases para la formación de un Plan General de Instrucción Pública", presentado en Sevilla ante la Junta Suprema de gobierno el 16 de noviembre de 1809, destinada a orientar las reformas que debía contener la Constitución de 1812.

${ }^{5}$ Mur de Víu, C. (2004). Colección de juegos y diversiones de Patrimonio Nacional. Piezas relacionadas con los juegos y los deportes. Jornadas Internacionales de Museo de Juegos y Deportes. Madrid, noviembre de 2004.
} 
como la sociedad decana en la promoción de la educación física y deportiva en España. ${ }^{6}$ A finales del siglo XIX se crearon el Veloz Club, la Gran Peña o el Polo Club. Muchos de ellos estuvieron auspiciados por los reyes, como es el caso del Real Club de Golf, ubicado en las proximidades del hipódromo madrileño. ${ }^{7}$

\section{La mujer y el deporte}

En el siglo XIX la idea de feminidad decimonónica no coincidía con los estereotipos de las deportistas. Asimismo, la práctica de deportes al aire libre por parte de las mujeres traía consigo que los rayos del sol bronceasen su piel, algo impensable entonces en una dama de la burguesía y la aristocracia que debía aparecer con una piel blanca y nunca curtida como la de las trabajadoras.

El barón Pierre de Coubertin, creador de los Juegos Olímpicos en 1896, redundaría en esta misoginia, argumentando que la presencia de la mujer en un estadio resultaba antiestética, poco interesante e incorrecta. Su actitud quedó claramente plasmada en esta frase que pronunció en los Juegos de Ámsterdam de 1928: «Para ellas la gracia, el hogar y los hijos. Reservemos para los hombres la competición deportiva». Sin embargo, las primeras mujeres que participaron en una edición de los Juegos lo hicieron en 1900 en París, en las modalidades de golf y tenis.

También en nuestro país, muchas publicaciones se cuestionaban el deporte femenino con afirmaciones como éstas:

«La debilidad de la mujer ha sido siempre su fuerza, y no resulta nada agradable ver á nuestras mismas hermanas desgreñadas y sudorosas rivalizar en sus esfuerzos con los del hombre para alcanzar un triunfo que casi siempre resulta grotesco. La gloria de los hombres es siempre su fuerza, sus proezas en las luchas de sport han sido su orgullo en todas las épocas; la mujer no igualará probablemente nunca las fuerzas del hombre, que han sido educadas por innumerables generaciones. Dejadnos reconocer que el sport como competencia física está absolutamente fuera de la esfera de la mujer, pero al mismo tiempo pensemos que el saludable ejercicio al aire libre es una necesidad para todo organismo viviente. La energía vital de un pueblo es el producto de sus madres; de una sana y bien desarrollada mujer nacerán niños robustos; así es que el único límite que debe ponerse al ejercicio al aire libre es el de privar á los deportes de un carácter de lucha. Así y todo, hay ciertos sports y pasatiempos que por su naturaleza debe impedirse su práctica a las mujeres.» ${ }^{8}$

A pesar de este rechazo al deporte femenino, ya en 1827 una publicación sobre la Educación Física de las mujeres abogaba por los beneficios que la llamada gimnástica tenía en la salud femenina:

«...cuando una muchacha robustece y fortifica su temperamento, corriendo por el campo, practicando ejercicios capaces de aumentar la elasticidad y vigor de sus miembros, respirando un aire perfumado por las emanaciones de los vegetales; cuando se acostumbra a repartir las horas entre las ocupaciones que su educación requiere y una serie de recreos inocentes y saludables; entonces el cuerpo adquiere su mayor grado de perfección.»9

Hacia 1880 se introdujeron nuevas ideas, provenientes principalmente de los médicos higienistas, que aconsejaron que poco a poco el deporte fuera practicado por miembros de ambos

\footnotetext{
${ }^{6}$ Rivero Herraiz, A. (2019): La Sociedad Gimnástica Española y los inicios de la educación física: una idea, un proyecto, una realidad (1887-1937). Citius, Altius, Fortius, 12(1), mayo, 2019. ISNN. 2340-9886. http://doi.org/10.15366/citius2019.12.1

${ }^{7}$ Pujadas, X., y Santacana, C., (2003). El club deportivo como marco de sociabilidad en España. Una visión histórica (1850-1975). Hispania, LXIII/2, nº. 214, p. 510.

8 «Intervención de las mujeres en el sport», Gran Vida, diciembre 1906, n 43. p. 2

9 Mora, J. J. de (1827). Gimnástica del bello sexo, o ensayo sobre la educación física de las jóvenes. Londres: Ackermann, P.X.
} 
sexos. Las revistas de la época abogaban por la importancia del deporte femenino y su influencia positiva en la salud de las mujeres, que en aquel momento se consideraban más débiles.

«Los Médicos que suscriben no saben cómo encarecer bastante una reforma de tanta importancia. En una gimnasia metódica, especialmente para señoritas, combinada con otros ejercicios corporales (la natación, el patinaje, los juegos en libertad), se encuentra el principal remedio a muchos males de los que afligen a las jóvenes. La gimnasia fortifica el sistema muscular, da gallardía al cuerpo, ensancha el pecho, que así respira más libremente, imprime firmeza a los movimientos y facilita el desenvolvimiento normal y armónico de los miembros y del organismo entero. E1 que la constitución de la mujer sea más débil y sus músculos más delicados, no es una razón para prohibirle los ejercicios corporales; lo único que debe hacerse, es tener en cuenta esa circunstancia.»10

Blanca Valmont, célebre cronista de moda, insistía en la idea de la necesidad de la práctica del deporte por parte de las mujeres. Así lo puso de manifiesto en un artículo aparecido en la revista «La Última moda»:

«Las jóvenes, tan propensas á la anemia, han encontrado en los novísimos preceptos de la moda el medio de conservar la salud, de vigorizar sus músculos dominando a los nervios, de tener excelente color y ostentar esa belleza sana de las mujeres que viven todo el año en el campo. No es sólo la bicicleta la que produce este milagro: quizás es el sport más perjudicial al bello sexo bajo todos conceptos; pero los juegos ingleses y norte-americanos del croket, el lawn-tennis y el polo, las excursiones, la vida al aire libre arrostrando las intemperies, contribuyen poderosamente a que las señoritas ostenten los atributos de la energía y la salud, prescindiendo de la languidez. poética, pero enfermiza, resabio del antiguo no menos enfermizo romanticismo.» ${ }^{11}$

Muchos autores defendían el deporte femenino, si bien dejaban claro que la mujer no podía dejar a un lado el principal objeto de su vida que era la maternidad.

«...Madama Daudet, la viuda del gran novelista, que tanta parte tiene en su gloria, habla discretísimamente. Cree que el ejercicio, la gimnasia, los sports, son necesarios para el desarrollo de las jóvenes, para su salud y para su alegría. No tienen entonces ocupación, ni pueden hacer cosa mejor que fortificar su cuerpo para las felices fatigas de la maternidad. Cuando ya es mujer, su misión está en el hogar. Odio á las que hacen de su casa un corredor para cambiar de vestido, un alto para la comida, en vez del clásico refugio, cuidado, limpio y ordenado, como en tiempos de nuestras abuelas y de nuestras madres.» ${ }^{12}$

En esta misma idea redundaba la revista Arte y sport al hablar de las bondades del golf para la mujer:

«...El desarrollo físico es un hecho en el golf. La mujer debe jugarlo porque es también motivo de lucir sus encantos, la gentileza de su figura toda en movimiento por la natural predisposición que siempre tiene la hermosa mitad del género humano a no verse vencida ni humillada, ni siquiera en los más sencillos juegos de sport.

Es, además, un antídoto contra los nervios y sus afecciones, contra las neurastenias y la tisis, que tantas víctimas hacen entre nuestra juventud, hoy dedicada a lecturas de novelas o al tango del cangrejo o del morrongo, que no nos parecen muy buenos pasatiempos para la salud y el desarrollo físico de la raza futura, aquella que ha de venir de madres enclenques y enfermizas. Con que a jugar al Golf.» ${ }^{13}$

\footnotetext{
${ }^{10}$ Sarda, A. (1882). «La Gimnasia», Instrucción para la mujer. Revista Quincenal. Madrid, 1 de octubre de 1882, $\mathrm{n}^{\circ}$ 15 , p.226.

${ }^{11}$ Valmont, B., (1897). La Última moda (Madrid). 26/9/1897, n. ${ }^{\circ}$ 508, p. 2.

${ }^{12}$ M. N. (1900). El Adelanto. Diario político de Salamanca, 13 de Julio, p. 2.

${ }^{13}$ Soda, C. (1903). "El golf", Arte y sport, 20 enero, p. 9.
} 


\section{Moda femenina y deporte}

A medida que el ejercicio femenino fue introduciéndose en la sociedad se hizo necesaria la creación de un traje adecuado que permitiera a las damas una cierta comodidad y libertad de movimientos. En este sentido, puede verse cómo, en los años finales del siglo XIX, fueron apareciendo en las diferentes revistas femeninas, comentarios y figurines con modelos que facilitaban la práctica de los diferentes deportes que en aquel momento se ponían de moda.

«...Las mujeres de hoy, si han de alzar el ski o practicar la aviación, tienen necesidad de prendas cuya hechura se asemeje á la del traje masculino, y que, si bien es cierto que unas y otras son por ahora excepciones, hay muchas que patinan y que tratan de llevar a este deporte un traje más adecuado que nuestras faldas estrechas, tan incómodas para practicarlo.» ${ }^{14}$

«...Es necesario - me dirán-vivir con la época, y en este siglo de los aeroplanos, los autos y los deportes á ultranza hay que buscar el lado práctico en los atavios femeninos. Nada impide á las sportswomen adoptar el traje masculino si es que las atrae su seca uniformidad. Pero reservémoslo exclusivamente para los deportes, ya que en todo tiempo la mujer verdaderamente elegante supo apropiar sus toaletas á las diversas circunstancias de la vida.» ${ }^{15}$

Como hemos apuntado, a partir del último tercio del siglo XIX van a ser constantes en las publicaciones femeninas las referencias, tanto escritas como gráficas, a la indumentaria que las mujeres debían llevar para la práctica de las actividades físicas. En todas ellas se repiten una serie de características que van a definir, a partir de aquel momento, el atuendo femenino para el deporte, y que se pueden resumir en las siguientes:

La moda para el sport se caracterizará, fundamentalmente, por ser práctica. El traje debe permitir libertad necesaria para moverse con soltura y comodidad a la hora de realizar una actividad física. En este sentido, el deporte propició una simplificación del traje femenino. Se eliminaron todos aquellos elementos superfluos y puramente decorativos, logrando hacer unos trajes prácticos y funcionales.

Gilles Lipovetsky en su obra El imperio de lo efímero. La moda y su destino en las sociedades modernas, pone de manifiesto estas nuevas características que van a definir el traje femenino para practicar deporte:

«...Se inició un proceso de reducción de la rigidez indumentaria que obstaculizaba la libre expresión de la individualidad. El deporte dignificó el cuerpo natural, permitió mostrarlo tal como es, desembarazado de las armaduras y trampas excesivas del vestir.

La simplificación de la indumentaria de los años veinte, la eliminación de frunces y perifollos en provecho de las formas sobrias, netas, es la respuesta a ese nuevo ideal de deporte, ligereza, dinamismo.» ${ }^{16}$

La indumentaria deberá seguir las normas imperantes en la moda. La mujer nunca podía perder su glamour en cualquier actividad diaria. Debía llevar modelos adecuados y elegantes de la mañana a la noche. Los diferentes artículos aparecidos en la prensa femenina ponen de manifiesto cómo el término ropa deportiva o sportwear comienza a ser utilizado para describir conjuntos simples y modernos que reflejan la nueva vida de la mujer activa, pero sin perder la elegancia que siempre debía acompañar a las damas:

«...Tiene, pues, una doble conveniencia el conocer la moda deportiva: el sello de elegancia que imprime a quien la adopta y las facilidades que concede en la práctica de los ejercicios físicos. ${ }^{17}$

\footnotetext{
${ }^{14}$ Castelfido, V. de (1911). Revista parisiense. Las faldas-pantalones. La moda elegante ilustrada, año LXX, n 13,6 abril, p. 146.

${ }^{15}$ Rodríguez, M. (1911). “Los conflictos de la falda-pantalón” Informaciones de Madrid, 23 de febrero, p.4.

${ }^{16}$ Lipovetsky, G. (1987). El imperio de lo efímero. La moda y su destino en las sociedades modernas, p. 85.

${ }^{17}$ Campillo, S del (1915). Los trajes para montar á caballo. Gran Vida. Madrid, diciembre. Núm. 151, p. 377.
} 
El traje deportivo debía estar fabricado en tejidos lavables, fáciles de mantener y con sistemas de cerramientos poco complicados. En este sentido, la nueva vestimenta para el sport va a propiciar, también, el empleo de novedosos materiales, más acordes con el ejercicio. Algunos de ellos se convertirán en protagonistas de la moda femenina; el algodón, la lana, la franela, el piqué o la alpaca, serán los principales.

\begin{abstract}
«Modelos que representan los grabados que publicamos, entre los que figuran trajes para ciclistas y amazonas, trajes de caza, para esgrima, excursión, paseos marítimos y juegos al aire libre. Para todos estos sports son preferidos los trajes confeccionados con tejidos de lana de alguna consistencia, tales como la sarga, la alpaca y las lanillas de género inglés, de colores claros u oscuros, amenizados con camisetas, plastrones o corbatas de sedalina o batista. Los sombreros o son de paja o de fieltro, tienen la copa alta sencillamente adornada con lazos y plumas y el ala bastante ancha para que proteja el rostro de los rayos de sol.» ${ }^{\mathbf{8}}$
\end{abstract}

Por último, el vestuario femenino para el deporte debía llevar detalles del traje masculino: camisas, chalecos, cuellos con corbatas, sombreros de copa o canotiers. Esto era una seña de identidad de los sastres que, en un principio, realizaban la indumentaria para el sport, tanto de los hombres como de las mujeres.

«...Pues bien: la práctica de estos diversos sports tan saludables; con los trajes y adornos que para ejecutarlos ha ideado la Moda, constituyen el Chic; y no hay duda de que las diversas aplicaciones de los modelos corte de sastre que dan cierto carácter varonil al traje femenino, resultan bonitos y hasta encantadores ${ }^{19}$

Dos prendas surgidas hacia 1850 pueden considerarse precursoras de la moda femenina para el sport: los bloomers y el traje sastre $o$ tailleur.

\title{
6. Los bloomers
}

Hacia 1850 surge en Norteamérica un fenómeno relacionado con el movimiento feminista, conocido con el nombre de «bloomerismo» y que tuvo como protagonista al traje.

Los antecedentes de este fenómeno hemos de buscarlos en un congreso celebrado en 1848: Seneca Falls Convention. Esta convención liderada por las feministas Lucrecia Mott y Elisabeth Cady Stanton, tenía como finalidad luchar de forma organizada por los derechos femeninos y exigir el derecho al voto de la mujer. De este Congreso nació la «Declaración de Seneca Falls», texto fundamental del Sufragismo Norteamericano.

Paralelamente, algunas feministas americanas llevaron a cabo una reivindicación relativa a la reforma del traje. Estas mujeres eran conscientes de la incómoda y nociva indumentaria imperante en aquellos años, con un corsé que apretaba la cintura y oprimía el pecho, y una crinolina que ahuecaba las faldas impidiendo la libertad de movimientos. Para liberar a las féminas de la tiranía de la moda, una de estas damas ideó un nuevo modelo más práctico e higiénico.

La creadora de esta novedosa vestimenta fue la activista Elizabeth Smith Miller, conocida como Libby Miller, quien en 1851 adoptó un «vestido racional» inspirado en los tradicionales trajes turcos. Esta indumentaria estaba compuesta por unos amplios pantalones bombachos que llegaban hasta el tobillo, y, sobre ellos, un sencillo vestido corto. El aspecto más novedoso de este traje consistía en la supresión del corsé y la crinolina.

Rápidamente, esta propuesta indumentaria llegó al conocimiento de otra feminista, Amelia Bloomer, quien fue su principal difusora.

\footnotetext{
${ }^{18}$ La Última moda (1900). Madrid. 15/7, n. ${ }^{\circ} 654$, p. 3.

${ }^{19}$ Valmont, B. (1897). Op. cit. La Última moda (Madrid). 26/9, nº 508, p. 2.
} 
Amelia Jenks Bloomer (Homer, New York 1818- Council Bluffs, Iowa 1894) era una destacada luchadora por la defensa del sufragio femenino y los derechos de las mujeres. Fue también editora de una revista femenina «The Lily» (1849-1855). Esta publicación, que llegó a tener una tirada de 4000 ejemplares, se convirtió en el vehículo perfecto para difundir sus ideas feministas en relación con la educación, la moda y el sufragio femenino. Desde un punto de vista reformista, reclamaba un papel más destacado e igualitario de la mujer en la sociedad. Su periódico fue también el principal vehículo para promover con entusiasmo este nuevo traje ideado por Libby Miler.

En el número de mayo de 1851 Amelia describió con detalle esta nueva indumentaria, recomendando su uso a «todas las mujeres con sentido común» con afirmaciones como las siguientes:

«... A vosotras, amas de casa, os decimos: Desabrochad vuestros vestidos y dejad que todas las prendas queden holgadas sobre vuestros cuerpos. Seguidamente, respirad a pleno pulmón, henchidos de aire tanto como podáis y en ese mismo instante abrochad la ropa. Cortad después esas faldas ondeantes hasta la altura de las rodillas y poneos unos pantalones holgados abrochados junto a los tobillos.» ${ }^{20}$

Este nuevo traje fue adoptado por las feministas como prenda cotidiana, convirtiéndose en su uniforme, sobre todo a la hora de dar conferencias por toda América y Europa propagando sus ideas a favor del sufragio femenino. Estas mujeres lo que pretendían era utilizar esta vestimenta como un elemento más para denunciar la situación en la que se encontraban las damas decimonónicas en este momento: su falta de derechos y su sometimiento a los caprichos de la moda que les obligaba a llevar un vestido que ellas consideraban absurdo y pernicioso para la salud femenina. Por ello, proponían una nueva indumentaria menos recargada y opresora, y más adecuada para la realización de una vida activa.

Los artículos relacionados con la propuesta de este traje reformista se multiplicaron tanto en América como en Europa. Muchas mujeres adoptaron conjuntos derivados de este estilo, que pronto se conoció con el nombre de su propio apellido: The Bloomer Costume o Bloomers. En España fueron conocidos como pantalones bombachos.

Como era de esperar, aquellas damas que adoptaron este nuevo atuendo fueron denostadas y ridiculizadas, siendo expulsadas de las iglesias y otros centros sociales. No se concebía, en aquel momento, que una mujer pudiera usar una prenda exclusiva de los hombres como eran los pantalones. Las revistas satíricas aprovecharon para burlarse de estas feministas, publicando caricaturas, dibujos y artículos jocosos que tuvieron a este novedoso traje como objeto de sus burlas.

Amelia Bloomer y su creadora, Elisabeth Smith utilizaron esta indumentaria durante 60 7 años, ya que les parecía un atuendo cómodo y práctico, que se adaptaba perfectamente al tipo de vida que ellas hacían. Las fuertes críticas y las presiones de la sociedad de su tiempo, hicieron que tuvieran que abandonar su novedoso vestido. La sociedad no estaba preparada para una revolución de este tipo.

Hubo que esperar hasta los años 80 para ver materializado el traje bloomer en el atuendo utilizado para la práctica de deportes como el ciclismo, la gimnasia o el alpinismo.

El fenómeno denominado «Bloomerismo» supuso uno de los más atrevidos intentos de las mujeres del siglo XIX por alcanzar unos derechos que entonces les eran negados y que tuvo en el vestido su protagonista involuntario. Como afirmaba en 1895 una revista de la época, este

\footnotetext{
${ }^{20}$ Neilson Gattey, C. (1970). Minifaldas en 1851. La osada moda de la señora Bloomer. Historia y Vida, ${ }^{\circ} 29$, agosto, p.41.
} 
movimiento fue, sin duda, la primera revolución acaecida en la indumentaria femenina del siglo XIX:

«Revolución femenina. Desde hace ocho años en que se inició en los Estados Unidos la rebelión de las mujeres contra las faldas, ha ido en crescendo el número de las que abandonan el traje usual en ellas. No tardando mucho, la mayoría de las ciudadanas de la libre América arrojarán despreciativamente los trajes hasta aquí en boga, para adoptar el introducido en ciertos ejercicios del sport.

El ensueño de las Bloomers de hace treinta años se halla a punto de convertirse en realidad, y el pretexto se encuentra en el ciclismo. Por eso hasta las más elegantes van al campo y se presentan en las grandes poblaciones vestidas con trajes que antes sólo se veían en las playas.

En los baños de Springfield un especulador acaba de construir un hotel monstruoso dotado de un velódromo magnifico. A la inauguración asistieron las mujeres más conocidas de América, que desfilaron en velocípedo ante una multitud distinguidísima, atraída por esta cabalgata de nuevo género, y, sobre todo, por la variedad de los trajes inéditos que se exhibieron, algunos de ellos con tal éxito, que causaron admiración profunda en la concurrencia, y han dado motivo para que se adoptaran como trajes de paseo, de excursiones y de sport. Pronto se verán en Central-Park realizando al fin el bello ideal del Congreso femenino de Chicago. Las mujeres no se contentan con presentarse en todas partes con pantalón bombacho fruncido en la rodilla, las piernas al aire y cubriendo el busto con blusa ceñida por un cinturón, sino que excitan a los hombres a seguirlas en este camino. El nuevo traje es ya general para el golf, el lawn tennis, la caza, la pesca, el yachting y el ciclismo.» ${ }^{21}$

La utilización del pantalón por parte de las mujeres fue un tema muy controvertido en la prensa del siglo XIX. Solamente se admitía en la práctica de los deportes, pero no como vestimenta para otras actividades. Así lo ponía de manifiesto una revista española al referirse a la moda de las faldas pantalones:

« ¿Veremos producirse en el traje femenino la revolución que profetizan algunos modistos, y reemplazadas por faldas pantalones, faldas sultanas?

...Hasta los más tradicionales entre los modistos, han sacrificado en aras del espíritu de la novedad y han ideado y preparado faldas - pantalones.

Lo prudente hubiera sido dejar esta hechura a las aviadoras, a las skiadoras; hacer con ella el traje especial para los ejercicios físicos, que es donde puede ser de utilidad y encontrar, por tanto, su razón de ser. Fuera de aquí no serán más que un alarde de rebeldía contra nuestras costumbres que han establecido diferencias radicales entre el traje femenino y el de los hombres. ${ }^{22}$

Sin duda, fue el ciclismo el deporte que más influyó en el desarrollo de esta novedosa prenda denominada bloomer.

En España la afición al ciclismo surgió con fuerza en el último tercio del siglo XIX con una doble vertiente de ocio y de competición; fue tanta la afición a este sport que se llegó incluso a hablar de la «locura velocipédica».

Las mujeres se incorporaron a este nuevo deporte, pero, a diferencia de los hombres, de una forma muy limitada, ya que como queda patente en un artículo aparecido en una revista de la época, la sociedad no veía con buenos ojos la práctica del ciclismo por parte de las féminas:

«La bicicleta-dice Champsaur—no ha hecho más que democratizar el deporte para la mujer. La coquetería del valor y de la sangre fría la tuvo siempre la mujer. Nos acompaña en estas gallardías

\footnotetext{
${ }^{21}$ El Correo Español. 24/9/1895, p. 1
}

${ }^{22}$ Castelfido, V. de, op. cit., p. 146. 
corporales, porque nuestra enemiga y compañera tiene el eterno deseo de rivalizar con el hombre $y$ de mostrársele en cada instante con un aspecto diferente». ${ }^{23}$

El uso de los bloomers por parte de las damas decimonónicas, imprescindibles para la práctica del ciclismo, supuso una revolución en la indumentaria femenina en nuestro país. Muchos veían en estos pantalones un ataque al decoro y la moral pública. Así se pone de manifiesto en un artículo aparecido en una revista de la época:

«... Saltando por encima de todo, logra la bicicleta en pocos días lo que no obtuvieron en muchos años las asociaciones y clubs femeninos propagandistas del Rational dress; es á saber que las señoras vistan calzón bombacho y que lo luzcan en público sin menoscabo de su nombre.

Las ciclistas llevan el pantalón bombacho por comodidad y nada más que por comodidad. Todas ellas han ido al ciclismo con el firme propósito de practicarlo vestidas con faldas; ninguna busca en el higiénico sport otra cosa que un ejercicio recomendado, una distracción perfectamente legítima y honesta, 6 un vanidoso deseo, esencialmente femenino. En efecto, la prenda indicada y la más cómoda para montar en bicicleta, y además tan airosa y susceptible de elegancia como donaire tenga y elegancia sepa darle quien la vista.

En Madrid no han pasado aun del calzón bombacho la indumentaria femenina, pero llegará el día que también aquí se celebren, como ya hace años ocurre en Londres, carreras de señoritas ciclistas, espectáculo tan interesante como provechoso para sus organizadores. Podremos entonces ver trajes en extremo caprichosos y originales, pues este sport se presta a la novedad y á la fantasía seguramente como pocos.» ${ }^{24}$

El éxito de este deporte y su práctica por las mujeres influyó en la aparición de diferentes publicaciones que orientaban a las ciclistas sobre cómo debían vestir. En este sentido, se publicó en Madrid, en 1895 un curioso libro: Prontuario del aprendiz y aficionado al velocípedo por dos compañeros de pedal. En él se reseñan una serie de preceptos resumidos en diez mandamientos destinados a la mujer ciclista:

«1. No llevarás corsé, sino jubón o justillo.

2. No usarás ligas de goma, lleva sencillamente cintas.

3. Usa pantalones de tela bien holgados y encima falda corta.

4. Lleva toca o capota y no te olvides del velo y de los guantes.

5. Guárdate como del fuego de la grosera vestidura del hombre.

6. Calza zapatos bajos que dejen libres tus pies.

7. Lleva contigo una falda arrollada al timón, te la pondrás cuando llegues al término del viaje.

8. De tal manera vestida pedalearás modesta y moderadamente.

9. Por término medio sólo andarás 12 o 15 leguas por día.

10. Por la noche acuéstate para reposar tranquilamente». ${ }^{25}$

Los historiadores consideran que fueron las mujeres ciclistas quienes más contribuyeron a la modernización de la indumentaria, abriendo el camino hacia los pantalones femeninos. En este sentido, Susan B. Anthony, célebre sufragista, dijo en 1896: «El ciclismo hizo más para emancipar a las mujeres que ninguna otra cosa en el mundo».

\footnotetext{
${ }^{23}$ M. N. (1900). El Adelanto. Diario político de Salamanca, 13 de Julio, p.2.

${ }^{24}$ El Pastor (1907). Nuevo Mundo, 25 de marzo de 1897, año IV n ${ }^{\circ} 168$ p. 9.

${ }^{25}$ Sáenz García, R. M. (2015). La mujer y la bicicleta en el siglo XIX, Valencia Universitat Jaume I, p. 51.
} 


\section{Figura 1}

El deporte velocipédico

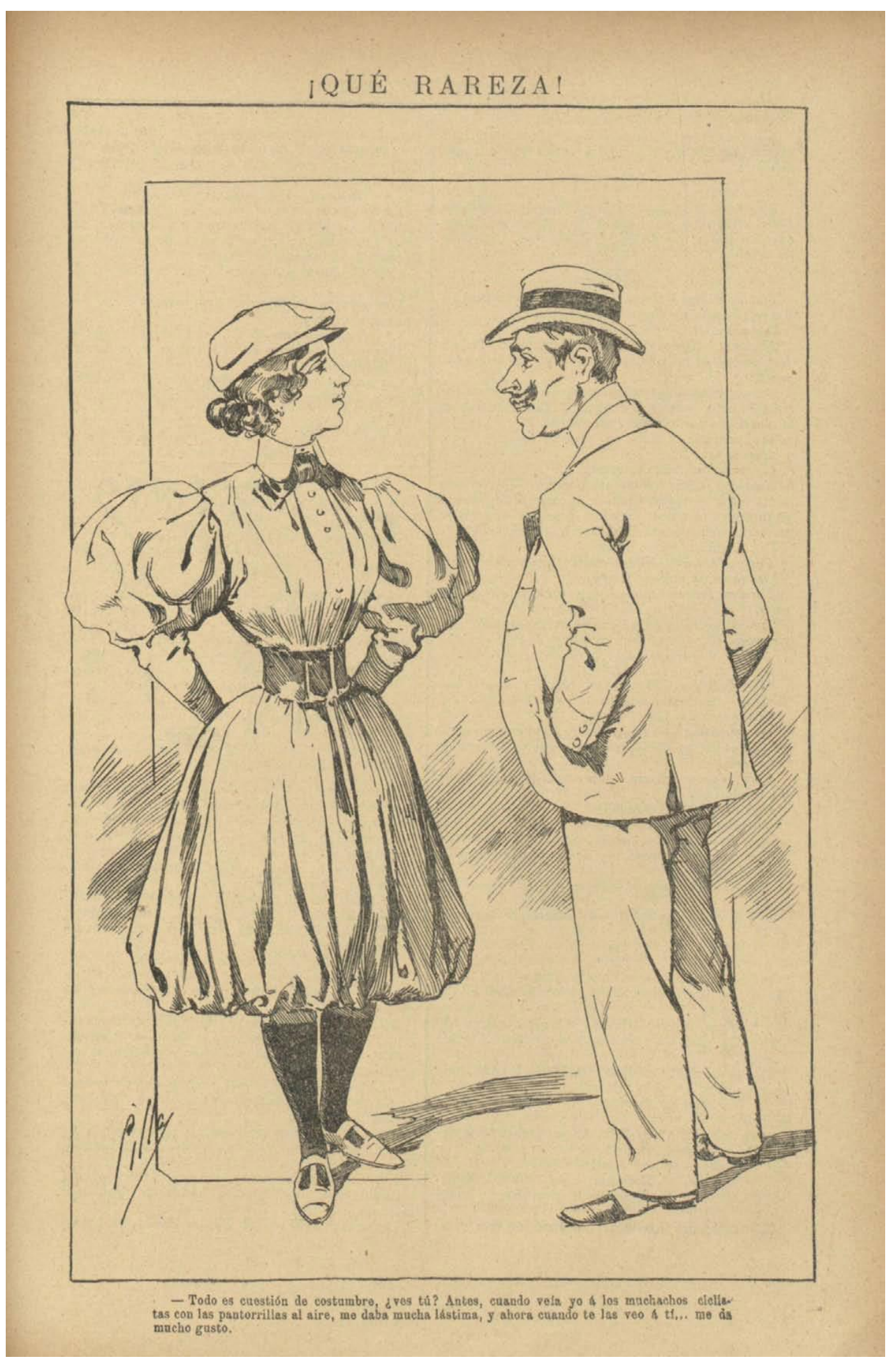

Nota. El deporte velocipédico, Madrid, miércoles 19 de agosto de 1896. Núm. 84, p..1. Dibujo de Cilla 


\section{El traje sastre}

El traje sastre constituyó uno de los avances indumentarios más novedosos de la moda femenina en los últimos años del siglo XIX y los primeros del siglo XX.

Creado hacia 1880 por el modisto inglés John Redfern, este atuendo estaba compuesto básicamente por tres piezas, una chaqueta, una falda, ambas de colores oscuros, y una blusa de color claro y despegada del cuerpo. Solía llevar, además, algunos complementos como un chaleco o una corbata, referencias asociadas al traje masculino.

Muchos fueron los nombres que recibió este modelo en las revistas de moda, atendiendo a sus orígenes o también a sus utilidades: traje sastre tailleur, tailor-made, «de chaqueta», trotteur, couteriére o «a la inglesa».

Elegante y práctico a la vez, permitía múltiples combinaciones de blusa, falda, chaqueta, chaleco, etc., de forma que con unas pocas prendas podían llevarse trajes diferentes. A partir de entonces el tailleur pasó a ser adoptado por un gran número de mujeres.

Una de las influencias del traje sastre hay que atribuírsela, sin lugar a duda, al atuendo de las amazonas. La hípica, que fue durante mucho tiempo una actividad practicada asiduamente por las damas, requería un modelo adecuado, consistente en una falda amplia, una blusa blanca y una chaqueta entallada. Estas prendas fueron posteriormente utilizadas en la estructura básica de esta indumentaria.

Fue el sastre inglés John Redfern quien diseñó y difundió los primeros tailleurs.

\subsection{John Redfern (1820-1895)}

Nacido en Inglaterra, se asentó como comerciante de telas en Cowes, dedicándose, en un principio, a adaptar las prendas que se utilizaban en el deporte de la navegación y aplicarlas a la indumentaria cotidiana. Los aristócratas y burgueses pudientes rápidamente se apresuraron a adquirir esta nueva ropa.

En 1878 Redfern se trasladó a Londres donde abrió su primera tienda. En ella vendía trajes realizados a medida. Su buen hacer llamó la atención de personajes famosos de la zona, entre los que se encontraba la actriz Lily Langtry, gran aficionada a las regatas. Para ella creó unos jerseys de lana los cuales tomaron su nombre del lugar donde se empezaron a realizar, la isla de Jersey.

Pero la fama de Redfern se debe, sin duda, a la creación del traje sastre. Muchos investigadores atribuyen su origen al vestido de viaje que el modista realizó para Alejandra de Dinamarca, mujer de Eduardo VII. La princesa pidió al modisto que le diseñara un traje de viaje. Para ella Redfern creó el costume tailleur, una vestimenta elegante que le proporcionaba mayor comodidad en sus desplazamientos y que estaba compuesta por una chaqueta, una falda y una camisa. En ella se eliminó cualquier elemento superfluo como el polisón, los lazos o los volantes. Se realizó en lana y algodón. Curiosamente, Redfern no suprimió el uso del corsé, prenda que no desapareció de la indumentaria femenina hasta 1910 de la mano de Poiret.

adaptación al deporte, actividad a la que se dedicaban muchas de las clientas de Redfern. Basándose en esta novedosa indumentaria, el modista inglés diseñó trajes para montar a caballo, jugar al tenis, o al golf, alcanzando un gran éxito entre las elegantes londinenses.

En una revista de la época se define a Redfern como el personaje que da origen al nacimiento de un nuevo tipo de indumentaria para el deporte: 
«John Redfern \&sons (...) el rey de esta indumentaria es Redfern (...) Realiza trajes para el lawntennis, croquet, yachting. Redfern ha creado los trajes 'tailleur' para mujeres que les proporciona libertad de movimiento, facilitándoles una ocasión de estar graciosas y bellas. Para los trajes de paseo y de sport es un maestro sin rival. Redfern combina el confort y la elegancia.» ${ }^{26}$

Su fama fue creciendo hasta llegar a convertirse en uno de los costureros más famosos de toda Inglaterra; prueba de ello es que en 1885 fue nombrado sastre real de la reina Victoria. femenina:

Max Von Bohen pone de manifiesto la influencia que el tailleur tuvo en la moda deportiva

«En relación al traje deportivo, en un principio solo se conocía el traje de amazona con larga cola; actualmente, además de éste, en el que la cola ha sido suprimida, tenemos los trajes especiales para el tennis, para los deportes acuáticos y para el alpinismo...Todos estos trajes proceden de Inglaterra....el traje práctico, al que pertenece el traje sastre, compuesto de falda, chaqueta y blusa, y para los trajes de los diferentes deportes, las inglesas dieron el tono; para el traje lujoso de los salones, sigue imperando París.» 27

El nuevo tailleur se convirtió en una prenda muy práctica y versátil, ideal para su

Las revistas femeninas del siglo XIX fueron explicitas en presentar figurines y comentarios relativos a la indumentaria utilizada en la práctica de los diferentes deportes. En estas reseñas se pone de manifiesto como el tailleur permitía a las damas ejercitarse en estas disciplinas deportivas con la elegancia que ninguna mujer debía perder nunca en cualquier actividad diaria. Así se refleja en las publicaciones de moda femenina en las que podemos leer comentarios sobre el traje utilizado en la práctica del patinaje, el lawn tennis o la equitación:

\subsection{El lawn tennis}

El tenis moderno tiene su origen en el siglo XIX. Era un deporte elitista reservado para la aristocracia que pasó a denominarse lawn-tennis. Se disputaban confrontaciones tanto amistosas como oficiales, pero siempre en el ámbito amateur.

Las competiciones femeninas de este deporte se iniciaron en Reino Unido en 1884 cuando la directiva del All England Croquet and Lawn Tennis Club, el más importante torneo de tenis en aquel momento, anunció la incorporación de la prueba de individual femenino. Dos mujeres pueden considerarse las pioneras del lawn tennis: Maud Edith Eleanor Watson (1864-1946) y Charlotte Dod (1871- 1960).

La indumentaria para practicar este deporte se componía de blusas de seda de manga larga, pero sin cuello, faldas largas con suaves bordados florales y sombreros de aire marinero. El traje se completaba con velos, guantes y zapatos con tacón. Posteriormente, se adoptó el color blanco que permitía disimular las posibles manchas de sudor provocadas por la actividad física.

En nuestro país este sport fue muy bien recibido, ejecutándose, igual que en gran Bretaña o Francia, tanto por hombres como por mujeres. En este sentido, las diferentes revistas femeninas del siglo XIX publicaron figurines y comentarios sobre la indumentaria que las damas debían llevar para su práctica.

\footnotetext{
${ }^{26}$ Le temps, 30 junio, 1891, p. 14.

${ }^{27}$ Bohen, M. von (1929). La moda. Tomo VIII. Siglos XIX-XX. 1879-1914, pp.188-189.
} 


\section{Figura 2}

Publición de «Les Modes»

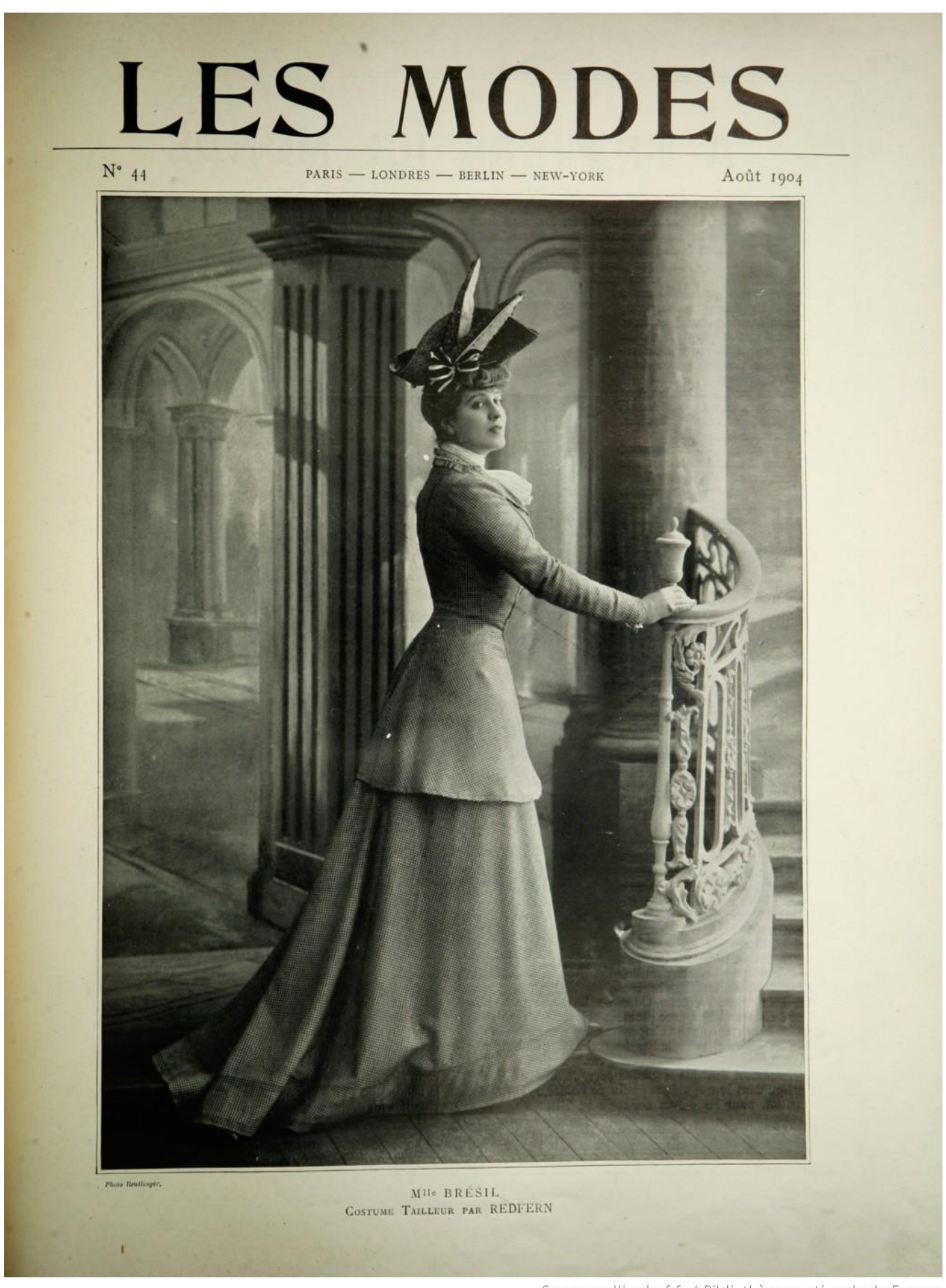

Nota. Revista «La mode et les modes», agosto 1904, No 44. Mlle Brésil luciendo un traje «tailleur» de Redfern 
«El Lawn-tenis. El juego del lawn-tennis se ha generalizado de tal modo en todas las estaciones veraniegas, que la necesidad se impone de dedicar alguna atención a las toilettes que la moda prescribe para dedicarse a tan agradable e higiénico pasatiempo;...Para los trajes lawn-tennis son elegidos con preferencia tejidos de lana, tales como sarga, franela diagonal; si bien se confeccionan así mismo bonitos modelos con piqué blanco o de color. Las faldas de los trajes que me ocupan, son rectas y semi-largas, montadas en pliegues o frunces y sencillamente adornadas con galones fantasía o cenefas bordadas. En los cuerpos, dos modelos-tipos gozan de igual favor: la chaquetilla corta, con grandes solapas, cuyos delanteros están sueltos sobre un plastrón de batista plegada, entallado por medio de una fajita de surah, y el cuerpo-blusa fruncido en el escote y la cintura y adornado con un gracioso cuello vuelto de etamine bordada o encaje irlandés. Las mangas del primer modelo, son de forma 'corte de sastre', y las del segundo, muy huecas, rematadas a la altura de la sangría con estrechos puños haciendo juego con el cuello. En estos trajes están muy admitidas las combinaciones de colores más fantásticas y atrevidas, siempre que no se hallen en abierta oposición con el buen gusto. Como el tocado más á propósito para lawntennis, citaré el sombrerito canotier de paja lisa, blanca o de color, sencillamente adornado con un lazo de cinta prendido con una hebilla de plata vieja ó acero oxidado. En cuanto al calzado, son de rigor las medias de hilo de Escocia negras, azul marino o granate oscuro, y las altas botinas de piel de Rusia o piel blanca cerradas con cordones de seda. ${ }^{28}$

\subsection{La Hípica}

La equitación constituía una práctica obligada entre los hombres y mujeres de la aristocracia y la nobleza desde tiempos inmemoriales. Era sobre todo un signo de distinción y de pertenencia a una clase social que podía adquirir y mantener este tipo de animales.

Para la práctica de esta actividad las damas utilizaban una indumentaria que permitía, no sólo cierta "comodidad" para cabalgar, sino que también debía ser glamuroso y elegante. En este sentido, todas las revistas de moda en las que se detalla el traje femenino para montar a caballo, hacen hincapié en la diferencia del que se utilizaba en las ciudades, realizado según la moda del momento, y el empleado por las amazonas en el campo, mucho más descuidado. Este hecho se refleja en una publicación de 1893:

«...Las mujeres de París llevan un atuendo de color negro con chaqueta con abertura en corazón sobre una camisa masculina en batista blanca con corbata blanca o negra. El sombrero es de copa.

Por su parte, las amazonas del campo emplean un estilo más informal utilizando prendas de colores en azul o verde y tocadas con un pequeño sombrero de fieltro. Una corta chaqueta ajustada y cerrada con una doble botonadura y corbata anudada al cuello. ${ }^{29}$

El traje de amazona del siglo XIX basado en el traje tailleur, era confeccionado por sastres que se inspiraban en las levitas y chaquetas masculinas y lo completaban con accesorios tomados de la indumentaria de los hombres como la corbata y el sombrero de copa.

«GACETA DE LA MUJER MODAS. "El traje de amazona vuelve a ser vistoso. En el extranjero ya hay quien lo adorna como si se tratara de un traje de paseo; pero no cabe duda que el vestido de montar, cuando es liso y serio, es el que más agrada y se estila. El sombrero lo mismo puede ser hongo que canotier alto y hasta de hechura tricornio. La falda moderna es corta; la chaquetilla, en cambio, es más bien larga, y como nota alegre, la corbata "plastrón» de piqué blanco; blanca también el amplio velo de tul para cualesquiera de dichos sombreros. Los guantes se parecen á la corbata y al velo... en que son claros. En esta época se lleva mucho el traje gris, de tela sumamente fina. Según una entusiasta "écuyére", hay tres categorías de amazonas: La que gusta de exhibirse á caballo. La que disfruta montando á caballo, y la que tiene cariño al caballo.» ${ }^{30}$

\footnotetext{
${ }^{28}$ La Última Moda (Madrid). 15/7/1894, n. 341 , p. 3.

${ }^{29}$ Condesa Xila (1893). La gran dame, revue de l'elegance et des arts, p. 242.

${ }^{30}$ El Imparcial, Madrid, 15 de mayo de 1902, p. 3.
} 


\section{Figura 3}

Publicación de «La Moda Elegante»
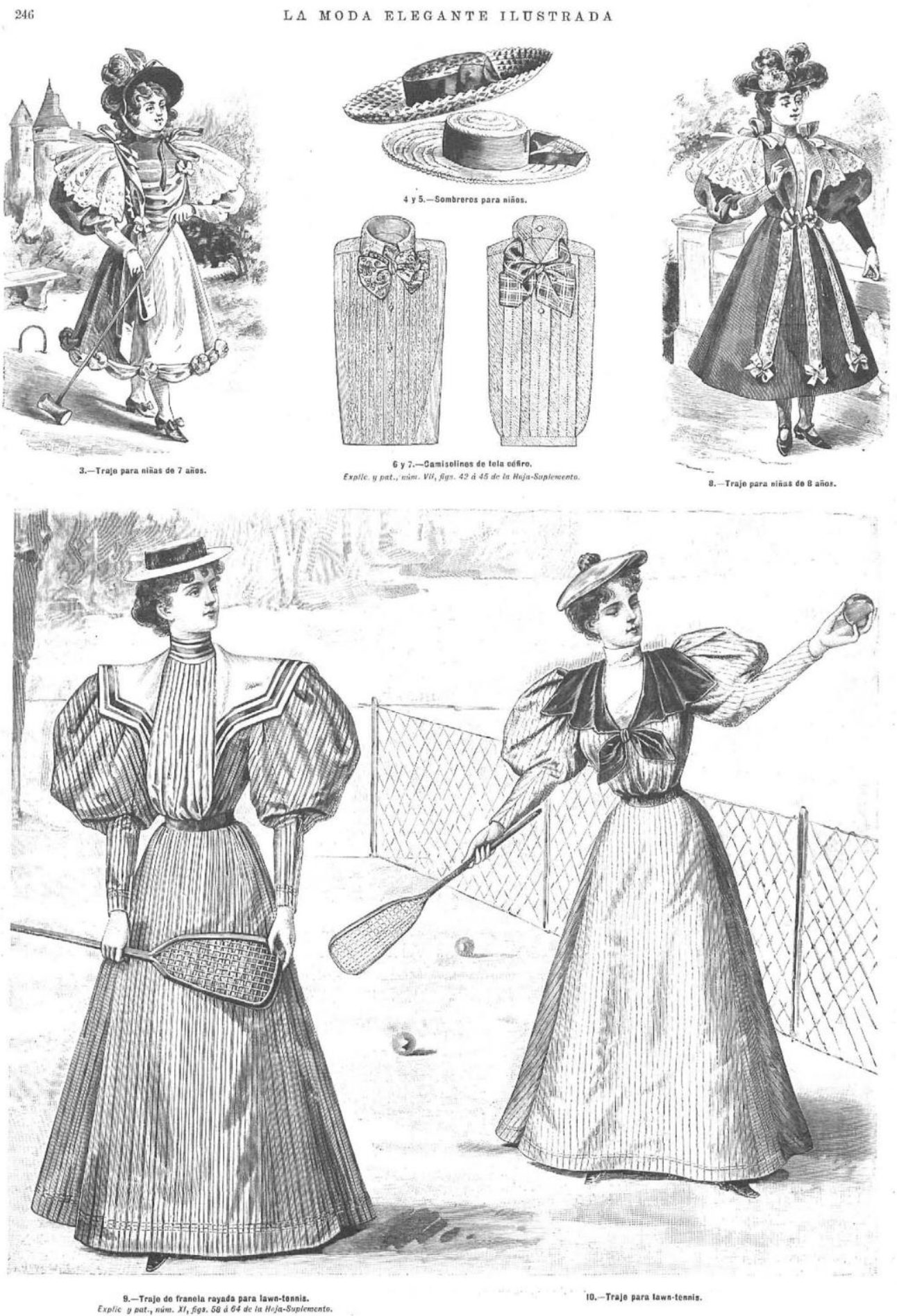

Nota. Figurines con trajes femeninos para jugar al tenis. La Moda Elegante (Cádiz). 6/6/1895, página 6. 


\subsection{Patinaje sobre hielo}

El patinaje nació como medio de transporte en zonas de clima frío ya que los patines se utilizaban para atravesar los canales congelados durante el invierno. Como deporte, su origen se remonta al siglo XIX. El primer campeonato de patinaje sobre hielo se celebró en el año 1882 en la ciudad de Viena.

En nuestro país, el patinaje sobre hielo se convirtió en una actividad de exhibición o ejercicio en parques públicos. Así lo narra una crónica aparecida en un diario madrileño:

«En Madrid se crean pistas de patinaje sobre hielo, como la de los Campos Elíseos, donde los amateurs puedan patinar, a cielo abierto, de manera segura y agradable; o la que se prepara en los estanques del Retiro, donde las superficies heladas, frecuentadas por los sportsmen madrileños y por las señoras, señoritas y manolas más elegantes, [demuestran] su destreza en el patín a los acordes de la música y el repiqueteo de las castañuelas. ${ }^{31}$

Las revistas de moda decimonónicas fueron especialmente explícitas en el comentario de la indumentaria que las mujeres debían llevar para la práctica de esta actividad deportiva.

«...describiré dos trajes deliciosos de patinar, que, después de todo, pueden servir de trajes de paseo.

El primero (croquis $n^{o}$. 1) es de terciopelo Victoria (de algodón) y cibelina color de piel. Encima del forro de seda van puestas dos grandes quillas de terciopelo sobre las cuales se abre la falda de cibelina. Un broche de pasamanería de seda reúne los dos paños por abajo, mientras que una tira estrecha de piel de skunga rodea todo el contorno. Chaqueta de cibelina, abierta sobre un peto de terciopelo. Unos broches de pasamanería en las caderas y unas hombreras de cibelina, guarnecidas de piel, caen sobre unas mangas de terciopelo. -Capotita de terciopelo Montmorency, lindo color de cereza muy nuevo, con estrellas de azabache y plumas negras.

El segundo traje (croquis $n^{o}$. 2), tan lindo como el primero, se compone de una falda y una chaqueta. La falda, enteramente lisa, es de terciopelo Olimpia negro con puntitos verdes. La chaqueta es de paño color de barro cocido, y va abierta sobre un chaleco de paño pergamino, adornado con dos solapas puntiagudas de terciopelo de seda. Un cuello del mismo paño «pergamino» desciende hasta la cintura, y va encañonado en los hombros. En el borde de las mangas, un puñito de terciopelo. Sombrero de fieltro "pergamino", adornado con cintas verdes de otomano y antenas de azabache.» ${ }^{32}$

\section{Fabricantes de ropa deportiva en España}

El auge que alcanzó el deporte en estos últimos años del siglo XIX, propició la aparición de diferentes sastres que se dedicaron a la fabricación de ropa deportiva.

Si Francia se convirtió en el siglo XIX en el adalid de la moda urbana para la mujer, Gran Bretaña, fue el país donde se originó y desarrolló la indumentaria deportiva o «sportwear».

Reino Unido ha sido tradicionalmente un país amante del campo y de las actividades al aire libre. Este hecho influyó de forma determinante en la creación de diferentes disciplinas deportivas: lawn-tennis, bádminton, etc., así como en su implantación y desarrollo en otros países europeos. Consecuentemente, los sastres ingleses tuvieron que crear una indumentaria adecuada para la práctica del deporte, surgiendo diversas casas de moda inglesas que se especializaron en este tipo de prendas. Las más famosas fueron: A.A. Tunmer, Henry Creed, Williams \& $\mathrm{C}^{\circ}$ y la Casa Burberry.

\footnotetext{
${ }^{31}$ La Iberia, 5 de febrero de 1876. La nota del diario español hace referencia a una crónica aparecida en el francés Journal des Débats.

${ }^{32}$ La Moda Elegante Ilustrada. Madrid, 30 de enero de 1894, n ${ }^{\circ}$. p. 37.
} 


\section{Figura 4}

Publicación de «El correo de la moda»

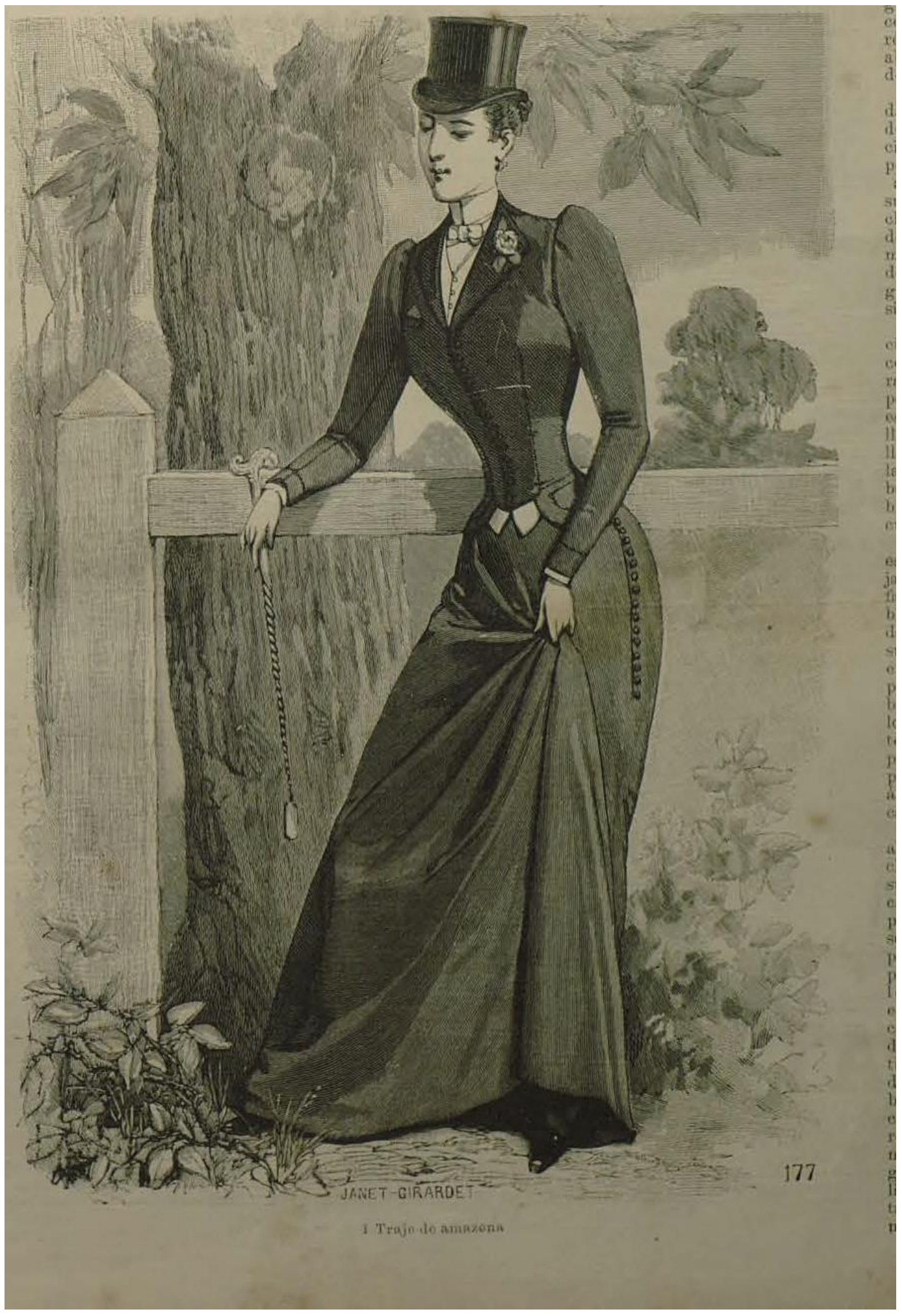

Nota. Traje de amazona. El correo de la moda, 10 de agosto 1892, p.1 
Para la práctica de los deportes también se hicieron necesarios complementos como maletas, guantes, zapatos, fustas, bolsos, arreos para el caballo, etc. Por ello se desarrollaron fábricas destinadas a proveer a estos sportmans de los accesorios adecuados. Éstos estaban destinados a un público urbano que demandaba complementos exclusivos como símbolo de distinción y que pudieran lucir en una urbe como París. Las más importantes fueron: la Maison Hermès, Vuitton o la Maison Verdier. Todas estas manufacturas tuvieron su origen en Francia, capital del lujo en aquellos años.

En nuestro país no fueron muy abundantes los sastres especializados en la confección de prendas deportivas. Así lo pone de manifiesto un artículo aparecido en 1907:

«...Pues mientras vemos que la moda en toilettes femeninas de calle y salón no se guía sino por el deseo de hacer más bellas y esbeltas á sus admiradoras, en cambio, cuando trata de imponer, por ejemplo, un traje para damas automovilistas, sólo tiene en cuenta los preceptos de la higiene y procura librarlas delirio, del polvo de las carreteras, de la lluvia y del viento. Claro es que para conseguir todo esto es muy difícil idear un vestido artístico y gracioso; y así se explica que, en estos tiempos en que el sport está en su apogeo, sean muy contados los sastres y modistas que hayan cobrado fama en este género. $»^{33}$

Pese a todo, sí podemos destacar a algunos sastres especializados en ropa deportiva como Moisés Sancha, nombrado proveedor del Rey D. Carlos I de Portugal. Tenía su taller en Madrid, en la calle de la Cruz, 12. Participó con gran éxito en el salón del automóvil de 1907, presentando diferentes prendas de vestuario y accesorios para la práctica del deporte. ${ }^{34}$

Pero sin duda, en España el modisto más célebre en este tipo de prendas fue Manuel Cimarra (1849-1921). Su andadura en la moda empezó en 1879 con la fundación de una empresa familiar: Manuel Cimarra hermanos (1879-1886), con sede en Madrid, en la calle del Carmen $n^{\circ}$ 15. Fueron constantes las referencias en la prensa a este importante sastre, al que se llegó a denominar artista de la indumentaria deportiva.

«... Confeccionar un traje de sport parece a primera vista cosa sencillísima, $y$, sin embargo, ofrece serias dificultades cuando ha de reunir las dos características que hemos señalado: elegancia y comodidad. Para asesorarse en esta materia, quizá no existe hoy en Madrid más que un sastre que merezca llamarse artista en la indumentaria deportiva, y ese artista de gusto depurado se llama don Manuel Cimarra.» ${ }^{35}$

Cimarra fue el representante en España de las casas de moda Strum y Casa Burberry. Fue nombrado Sastre de Cámara de S.M. el rey de España, Alfonso XIII, que como hemos apuntado anteriormente era un gran aficionado al deporte.

Su fama y buen hacer propiciaron su participación en la Primera Exposición de automovilismo, ciclismo y deportes, celebrada en Madrid en 1907. Una noticia aparecida en la revista Gran Vida así lo reseñó:

«...D. Manuel Cimarra. MADRID. Participó en la exposición de 1907. En las dos elegantes vitrinas pertenecientes al sastre predilecto de los sportsmen y de los aristócratas, podemos fijarnos en los últimos modelos de guardapolvos y abrigos para señoras y caballeros, tan prácticos como elegantes.» ${ }^{36}$

D. Manuel Cimarra murió en 1921 a los 72 años de edad.

\footnotetext{
${ }^{33}$ Gran Vida. Revista ilustrada de sports, 44, 1 de enero, de 1907, p.23.

${ }^{34}$ Gran Vida, mayo de 1907, no 48, p. 40.

${ }^{35}$ Campillo, S. del (1915). Los trajes para montar a caballo. Gran Vida, diciembre, ${ }^{\circ}$ 15, p. 377.

${ }^{36}$ La moda en el sport (1907). Gran Vida. Revista ilustrada de sports, $\mathrm{n}^{\circ}$ 44, enero, pp.23-25.
} 


\section{Figura 5}

Publicación de La Moda Elegante Ilustrada

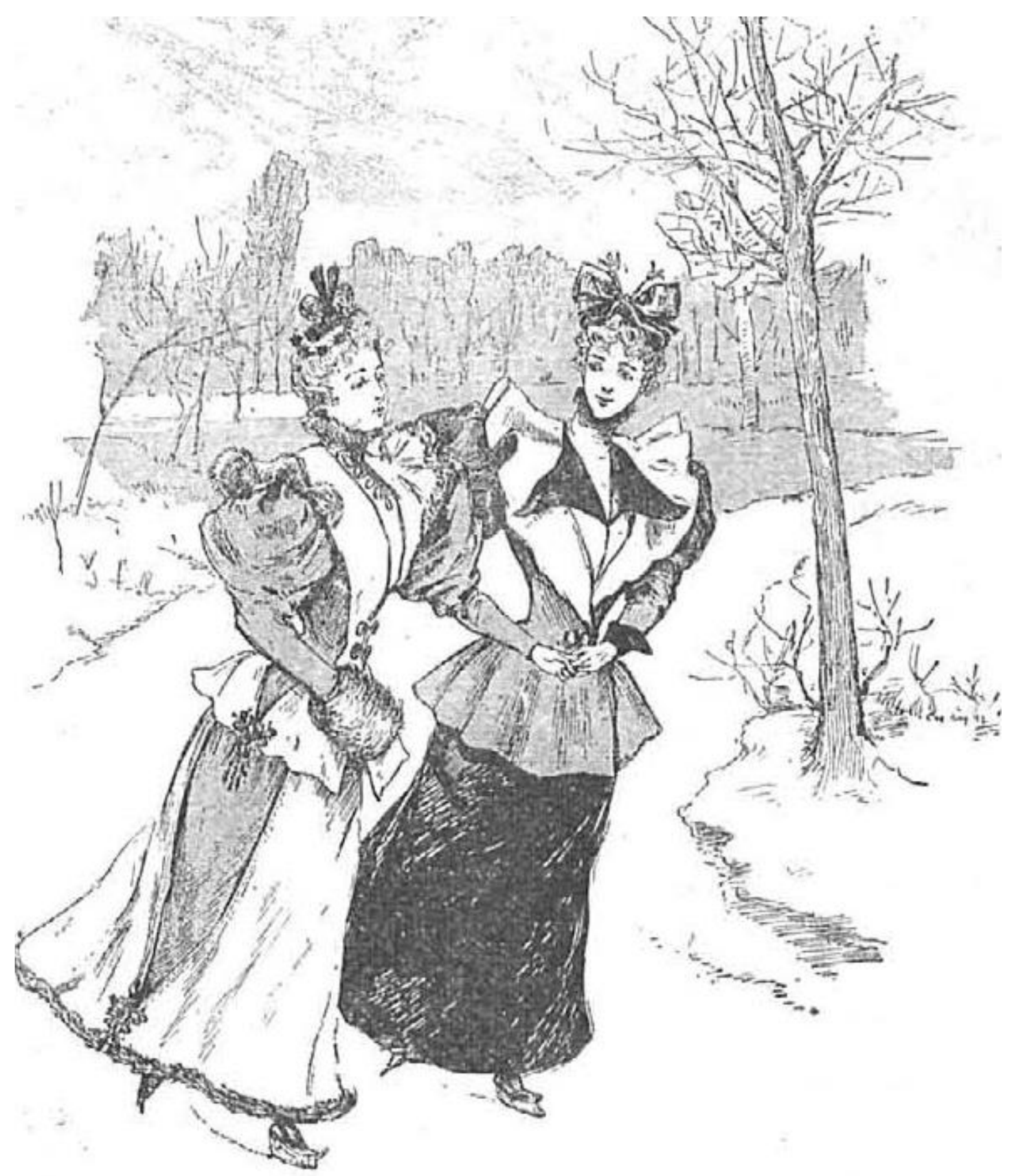

Nims. 1 y 2.

Nota. La Moda Elegante Ilustrada. Madrid, 30 de enero de 1894. nº 4, p. 38 


\section{Figura 6}

Anuncio de la publicación «Gran Vida»

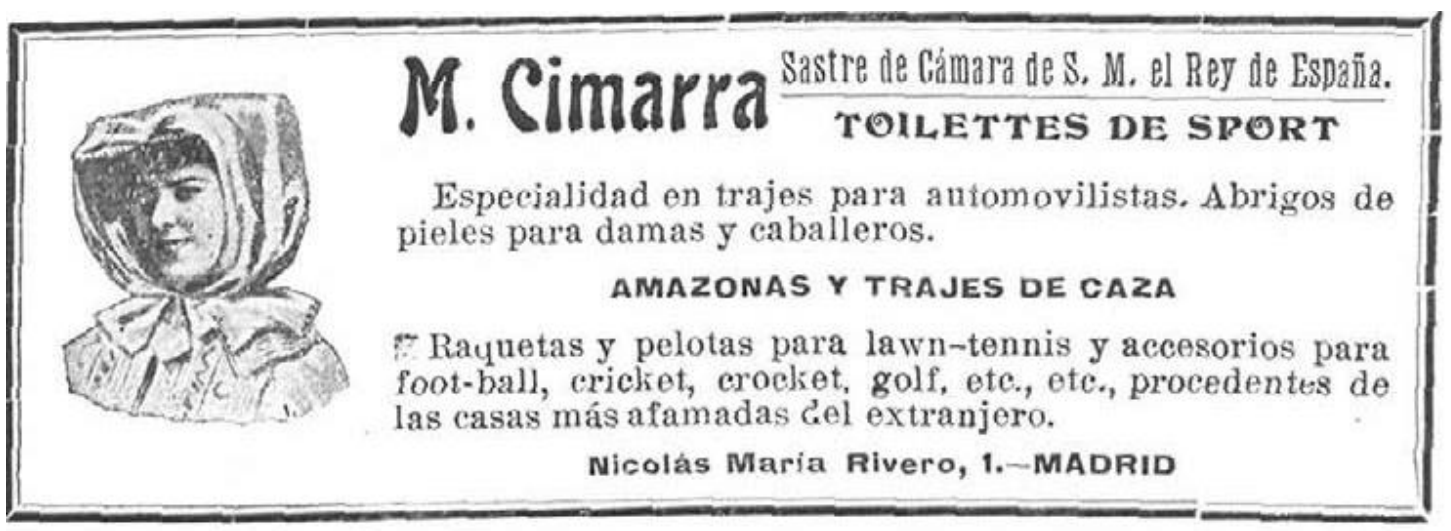

Nota. Anuncio de la sastrería de Cimarra aparecido Gran Vida. Año VI, no 65. 1-10-1908

\section{Conclusiones}

A partir del último tercio de siglo XIX el deporte empezó a formar parte de la vida de las mujeres en nuestro país. La práctica del sport trajo consigo unas nuevas costumbres que se materializaron en un cambio de la estética femenina y de la indumentaria. Se creó un novedoso vestuario más sencillo, que permitía una mayor libertad de acción, y que se adaptaba a estas actividades al aire libre.

A partir de 1910 la indumentaria femenina se fue modernizando. Modistos como Poiret o Mariano Fortuny con su vestido «Delphos», desterraron el corsé del traje de la mujer, las faldas se acortan progresivamente, y los pantalones entraron a formar parte del vestuario de las damas. Todos estos cambios contribuyeron a difundir esta nueva imagen de la mujer activa, moderna e independiente que va a llenar parte de su vida ociosa con el deporte.

El auge que poco a poco alcanzaron en nuestro país los diferentes sports como el ciclismo, el golf, el lawn tennis o el patinaje, entre otros, propiciaron la aparición de sastres y modistas especializados en la indumentaria deportiva. También los grandes almacenes que fabricaban en serie este tipo de prendas vieron incrementada su clientela. Las revistas femeninas y, sobre todo, las publicaciones deportivas, fueron fundamentales en la difusión de la moda para el sport.

\section{Bibliografía}

- California: Praeger, cop.

- Anónimo. (1906). Intervención de las mujeres en el sport, Gran Vida. Revista ilustrada de sports, diciembre, $\mathrm{n}^{\circ}$ 43. pp.1-5.

- Anónimo. (1907). La moda en el sport, Gran Vida. Revista ilustrada de sports, no 44. enero, pp.23-25.

- Anónimo (1895). Revolución femenina, El Correo Español. 24/9/, p. 1.

- Bohen, M. von (1929). La moda. Tomo VIII. Siglos XIX-XX., Barcelona, Salvat.

- Campillo, S. del (1915). Los trajes para montar a caballo. Gran Vida. Madrid, Diciembre, ${ }^{\circ}$. 151, pp. 377-379. 
- Castelfido, V de (1911). Revista parisiense. Las faldas-pantalones. La moda elegante ilustrada, año LXX, n 13, 6 abril, p. 146.

- Clemente García, E. (1999). Notas sobre indumentaria y feminismo revolucionario. Emblemata, 5, 441-454.

- Contecha Carrillo, L. F. (2000). Mujer y olimpismo, 2000, http://www.efdeportes.com, 24. Agosto.

- Corona Verdú, R. (2017). La emancipación femenina decimonónica a través del denuedo velocipédico, Femeris, 2(2), 119-136. https://doi.org/10.20318/femeris.2017.3761 http://www.uc3m.es/femeris [Consultado 24-8-2018].

- Cunningham, P. (2003). Reforming women's fashion 1850-1920. Politics, health and art. London.

- Dubois Rubio, C. (2014). La mode aux courses : Un siècle d'élégance (1850-1950).

- Erskine, F.J.(2014). Damas en bicicleta. Cómo vestir y normas de comportamiento. Madrid, Impedimenta. (Edición facsímil de la obra publicada en 1897).

- Franque, A. (2018). Et le «bloomer» libéra le corps des sportives. Liberation, 8 décembre https://www.liberation.fr/sports/2018/12/08/et-le-bloomer-libera-le-corpsdessportives_1696434 [Consultado 8-3-2019]

- Grasse, M.C. (2015) En Mode Sport, (cat.exp.), Nice, Musée du Sport, du 12/06/2015 au 20/09/2015.

- Izquierdo Macó, E. Gómez Alonso, M.T. (2001). La difícil incorporación de la mujer a la "locura" velocipédica del siglo XIX, Buenos Aires, año 7, n 43, diciembre.

- Jamain-Samson, Sandrine, Thierry Terret. (2009). Fabricants, détaillants et vendeurs : l'économie du costume de sport à la Belle Époque. Staps, 83(1), 55-67. http://www.apses.org/IMG/pdf/clio-1877-23- https://doi.org/10.3917/sta.083.0055

— Jiménez Mancha, J. (2004). El Veloz Club AIEM, XLIV, 555-568.

- Laprade, M. (2017). Haute couture et expositions universelles, 1900-1925, Apparence(s) [En ligne], 7 | 2017, mis en ligne le 01 juin 2017.

URL http://journals.openedition.org/apparences/1370

- Lipovetsky, G. (1987). El imperio de lo efímero, La moda y su destino en las sociedades modernas. Barcelona, Anagrama.

- Martínez Navarro, A. (1983). Anotaciones a la historia de la educación física española en el siglo XIX. Historia de la educación: Revista interuniversitaria, 2, 153-164.

http://campus.usal.es/ revistas_trabajo/index.php/0212 0267/article/viewFile/6476/6478 [Consultado 3-11-2010]

- Martínez-Gorroño, M.E. y Hernández-Álvarez, J.L. (2014). La Institución Libre de Enseñanza y Pierre de Coubertin: la educación física para una formación en libertad / The free institute of education and Pierre de Coubertin: physical education to educate within liberty. Revista Internacional de Medicina y Ciencias de la Actividad Física y el Deporte vol. 14 (54), 243263. $\mathrm{Http}: / /$ cdeporte.rediris.es/revista/revista54/artinstitucion458.htm 
- Mora, J. J. de (1827). Gimnástica del bello sexo, o ensayo sobre la educación física de las jóvenes. Londres, Ackermann.

- Morais-Alexandre, P. (2010). O Ténis e a Moda, Escola Superior de Teatro e Cinema.

- Muntañola, M. T. (1996). Evolución del deporte del tenis, Apunts, Educación Física y Deportes, (44-45), 12-18.

- Mur de V, C. (2004). Colección de juegos y diversiones de Patrimonio Nacional. Piezas relacionadas con los juegos y los deportes. Trabajo presentado en las Jornadas Internacionales de Museo de Juegos y Deportes. Madrid, noviembre.

- Pujadas, X. y Santacana, C. (2003). El club deportivo como marco de sociabilidad en España. Una visión histórica (1850-1975). Hispania, LXIII/2, nº. 214, 505-522.

https://doi.org/10.3989/hispania.2003.v63.i214.222

- Rivero Herraiz, A. (2004). Los orígenes del deporte español: el desarrollo de un nuevo componente cultural urbano. Kronos: la revista científica de la actividad física y el deporte, 6 , julio-diciembre, 29-33.

- Rivero Herraiz, A. (2019). La Sociedad Gimnástica Española y los inicios de la educación física: una idea, un proyecto, una realidad (1887-1937). Citius, Altius, Fortius. Humanismo, sociedad y deporte: investigaciones y ensayos, 12(1), 37-49. Mayo, 2019. ISNN. 2340-9886. http://doi.org/10.15366/citius2019.12.1

- Rodríguez, M. (1911). Los conflictos de la falda-pantalón. Informaciones de Madrid, 23 de febrero, p.4.

- Neilson Gattey, C. (1970). Minifaldas en 1851. La osada moda de la señora Bloomer. Historia y Vida, n $^{\circ} 29$, agosto, pp. 36-47.

— Sáenz García, R. M. (2015). La mujer y la bicicleta en el siglo XIX, Valencia Universitat Jaume I.

- Saint Martin, M. de (1989). La noblesse et les "sports" nobles. Actes de la recherche en sciences sociales, vol. 80, $\mathrm{n}^{\circ} 1$, pp. 22-32. https://doi.org/10.3406/arss.1989.2913

- Sampedro Martínez, J. I. (2005). La mujer y el atletismo. Un largo camino hacia la paridad. efdeportes.com, $\mathrm{n}^{\circ}$ 86. julio.

- Sánchez Menchero, M. (2009). Cinco cuadros al fresco. Los jardines de recreo en Madrid (1860-1890). Culturales, 5(9), enero-junio, 141-168.

- Torrebadella Flix, X. (2013). La Educación Física femenina en el período isabelino (18331868): Teresa Castellanos de Mesa, primera profesora española de gimnástica. Ágora para la EF y el Deporte, 15, enero - abril, 20-39.

- Torrebadella Flix, X. (2011). La educación física y la actividad gimnástico- deportiva de las mujeres a partir de la bibliografía especializada del siglo XIX. Arenal, 18:1; enero-junio, 147179.

- Valmont, B. (1897). La Última moda (Madrid). 26/9, n. ${ }^{\circ}$ 508, p.2.

- Williams, J. (2014). A Contemporary History of Women's Sport. Part one. Sporting women 1850-1960. New York, Rouledge. https://doi.org/10.4324/9781315795157 